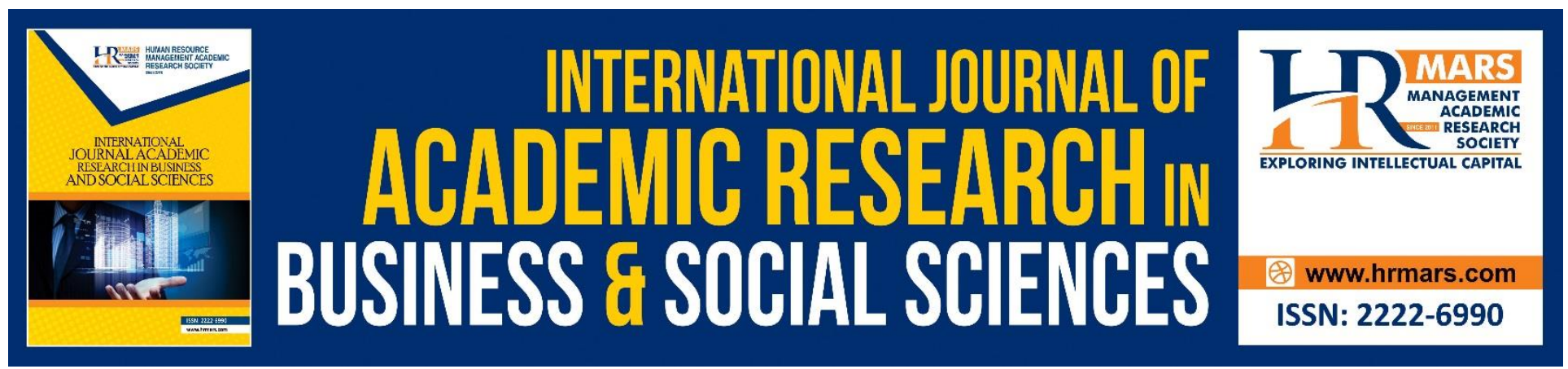

\title{
Trade Credit, Debt Finance Structure and SMEs Growth in Rwanda
}

\author{
Emmaboles Rubunda, Gregory. S. Namusonge, Oluoch Oluoch
}

To Link this Article: http://dx.doi.org/10.6007/IJARBSS/v9-i6/5918

DOI: $10.6007 /$ IJARBSS/v9-i6/5918

Received: 16 April 2019, Revised: 05 May 2019, Accepted: 30 May 2019

Published Online: 17 June 2019

In-Text Citation: (Rubunda, Namusonge, \& Oluoch, 2019)

To Cite this Article: Rubunda, E., Namusonge, G. S., \& Oluoch, O. (2019). Trade Credit, Debt Finance Structure and Smes Growth in Rwanda. International Journal of Academic Research Business and Social Sciences, 9(6), 2443.

Copyright: (C) 2019 The Author(s)

Published by Human Resource Management Academic Research Society (www.hrmars.com)

This article is published under the Creative Commons Attribution (CC BY 4.0) license. Anyone may reproduce, distribute, translate and create derivative works of this article (for both commercial and non-commercial purposes), subject to full attribution to the original publication and authors. The full terms of this license may be seen

at: http://creativecommons.org/licences/by/4.0/legalcode

Vol. 9, No. 6, 2019, Pg. 24 - 43

http://hrmars.com/index.php/pages/detail/IJARBSS

JOURNAL HOMEPAGE

Full Terms \& Conditions of access and use can be found at http://hrmars.com/index.php/pages/detail/publication-ethics 


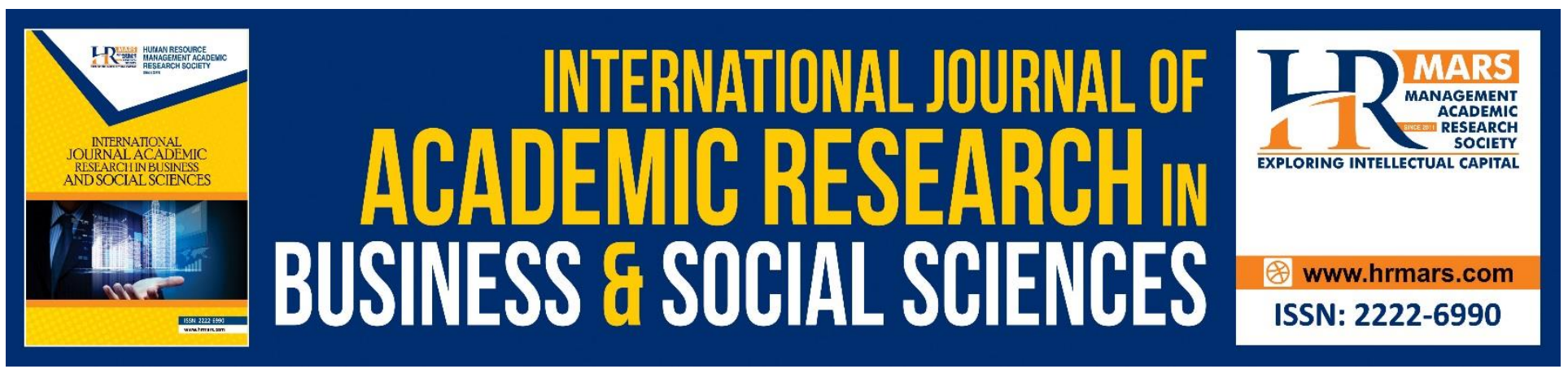

\title{
Trade Credit, Debt Finance Structure and SMEs Growth in Rwanda
}

\author{
Emmaboles Rubunda \\ PhD Candidate Jomo Kenyatta University of Agriculture Technology Kenya \\ Prof. Gregory. S. Namusonge, Dr. Oluoch Oluoch \\ Jomo Kenyatta University of Agriculture and Technology, Nairobi, Kenya \\ Email: gsnamusonge@jkuat.ac.ke, oluochjoluoch@gmail.com, erubunda@yahoo.co.uk
}

\begin{abstract}
This study examined the influence of trade credit and debt finance structure on the growth of SMEs in Rwanda guided by two specific objectives; to investigate the influence of trade credit finance structure on the growth of small and medium manufacturing enterprises in Rwanda and to evaluate the influence of debt finance structure on the growth of small and medium manufacturing enterprises in Rwanda. The study used mixed research design for collecting, analyzing and integrating data using a target population of all the 868 small and medium manufacturing enterprises registered with Rwanda Development Board. Stratified random sampling technique was used to draw a sample size of 273 SMEs. Close-ended questionnaires were used in data collection and data was analyzed by way of Statistical Package for Social Science (SPSS) to generate descriptive statistics. Multiple regression analysis was used to explore the relationship between trade credit, debt finance and growth of small and medium size manufacturing enterprises in Rwanda. Analysis of variance (ANOVA) was utilized to test the significance of the model. Results of $R^{2}$ indicted the goodness fit of the regression model. Study findings show that trade credit finance structure has a positive and significant effect on growth of small and medium manufacturing enterprise in Rwanda while results on debt finance structure were found to be insignificant. Based on these findings, the study recommends that stakeholders should ensure availability of various financing options for SMEs in Rwanda.
\end{abstract}

Keywords: Debt Finance Structure, Trade Credit Structure, Sme Growth 
INTERNATIONAL JOURNAL OF ACADEMIC RESEARCH IN BUSINESS AND SOCIAL SCIENCES Vol. 9, No. 6, June, 2019, E-ISSN: 2222-6990 @ 2019 HRMARS

\section{Introduction}

Small and medium-sized enterprises (SMEs) form the backbone of most national economies around the world (OCDE, 2018) and as Akinyi (2012) observed, in both advanced economies and developing countries, SMEs contribute on an average, 60 percent of total formal employment in the manufacturing sector. In the European Union (EU), they represent $99 \%$ of all businesses (EU, 2018) while in Africa, the role of the SME sector to job opportunities is far more significant. Considering the contribution of the informal sector, SMEs account for about $75 \%$ of total employment in manufacturing in many African economies (Akinyi, 2012). Yet, SMEs face serious difficulties in accessing finance, both via banks and financial markets as Andries, Marcu, Oprea, Tofan (2018) highlight that smaller businesses have reduced access to financial markets and they suffer more restrictions regarding credit.

Debt financing for SMEs in developing countries such as Rwanda is mainly limited to bank loans and trade credit (OECD, 2006). According to Rungani (2009) commercial banks are the major source of debt finance for new SMEs. They offer new SMEs a variety of services which cover every aspect from the financial to market; overdraft facilities, term loans, trade bill financing, factoring, leasing, export and import finance and even government loan guarantee schemes (Akinyi, 2012). Furthermore, trade credit is highlighted as another key source of finance for SMEs. Studies indicate that in the European Union, trade credit accounts for approximately 30\% of GDP (OECD, 2018) and more specifically in EU SMEs, trade credit is the key source of SME funding after financial intermediaries (Kwaak, Van der Graaf and Van der Zeijden, 2016). Thus, trade credit in SMEs plays a major role in the provision of finance for investment (Bancilhon, Karge, Norton, 2018).

In Rwanda, there is limited access of SMEs to credit and financial services as one of the most critical supply bottlenecks confronting the sector (Ndikubwimana, 2016). According to Ministry of trade and commerce, MINECOM (2010) small businesses in Rwanda have a great deficiency as far as availability of credit is concerned, which requires special attention of bankers, if such businesses are to grow. MINECOM further highlights that most SMEs that wish to grow find it difficult due to insufficient operating and investment capital. Hence, rooted in the credit rationing and pecking order theories of finance structure, this study examined the influence of debt finance structure (trade credit and debt finance) on the growth of small and medium size manufacturing enterprises in Rwanda. The study suggests solutions aimed at filling the existing gaps in terms of financing for SMEs in Rwanda particularly through trade credit and debt finance and thereby contributes to enhancing better channeling of funds by the supplying units to SMEs.

\section{Statement of the Problem}

According to Hussain, Turab, Khan, Malik and Faheem, (2012) globally, SMEs complain of growth and competitiveness constraints associated to limited access to financial resources. SMEs ability to easily access finance and expand business is barred by collateral requirements as well as unexplained bank charges (Garikai, 2011) which hinder their accessibility to finance to help them to expand. Collateral, interest rates, extra bank charges, inability to evaluate financial proposals and lack of financial management skills also limit the growth of SMEs (Stiglitz and Weiss, 2011). Given such shortcomings, SMEs often resort to informal sources of credit, though with high interest rates. Hence, informal credit sources constitute very substantial contributions to business start-ups in developing countries 
(Mwangi and Otieno, 2013). They however increase SMEs' vulnerability to heavy reliance on owners' internally generated finances. According to Ministry of trade and commerce, MINECOM (2010) small businesses in Rwanda have a great deficiency as far as availability of credit is concerned. Given such background, it is quite evident that there is an existing financing gap for SMEs in the country. Moreover, there is a gap in literature relating to the subject which justifies this research with a focus on the influence of trade credit and debt finance structure on the growth of small and medium manufacturing enterprises in Rwanda. The findings of this research will contribute to bridging the financing gap for SMEs through suggesting avenues to better channel finances for SMEs by the supplying units.

\section{Specific Objectives}

i. To investigate the influence of trade credit finance structure on the growth of small and medium manufacturing enterprises in Rwanda.

ii. To evaluate the influence of debt finance structure on the growth of small and medium manufacturing enterprises in Rwanda

\section{Research Hypothesis}

1. $\mathbf{H O}_{1}$ : There is no significant influence of trade credit finance structure on the growth of small and medium manufacturing enterprises in Rwanda.

2. $\mathbf{H O}_{2}$ : There is no significant influence of debt finance structure on the growth of small and medium manufacturing enterprises in Rwanda.

\section{Theoretical Review}

\section{Credit Rationing Theory}

Credit rationing theory as propounded by Stiglitz and Weiss (1981) cited in Malhotra, (2015) which elaborates a framework for analyzing financial market inefficiencies that affect credit financing. The theory asserts that, information asymmetry is the main cause of financial market malfunctioning in developing countries which hinders credit allocation and leads to credit rationing. Lending institutions that advance credit to economic agents are not only interested in the interest income that accrues on credit facilities, but also the risks of such facilities (Helsen, 2014). According to these authors, the interest that banks charge on loans have the tendency to affect the risks of a pool of loans by either sorting potential borrowers (adverse selection effect) or affecting the behavior of borrowers (moral hazard effect).

Relating this theory to the study variables, the theory posits that credit financing has positive effect on profitability and therefore efforts should be undertaken to enhance it. However, the process of availing credit to users is faced by limitations which ration the amount available to the borrowers. As a result, lending institutions try to resolve the problem by resorting to various screening mechanisms to identify potential borrowers who are more likely to pay back credit advanced to them, since expected return on such credit depends significantly on the probability of repayment (Malhotra, 2015). One of the methods of screening suggested by Stiglitz and Weiss is the interest rate that an individual is willing to pay. This is because, given the efficient financial markets hypothesis, individuals who are willing to pay high interest rates may on the average not pay back credit advanced and banks 
are mostly discouraged to give loans to such borrowers (Helsen, 2014). On the other hand, low risk borrowers, faced with high interest rates, ceteris paribus, will be expecting negative returns and hence will not go for such loans. Therefore, in the world today where individuals have unlimited access to information they need, banks could precisely predict all actions by borrowers but may not be able to control such actions. Terms of lending are thus made by lending institutions in a way that induces borrowers to take actions in the institutions' interest (Malhotra, 2015).

Stiglitz and Weiss (1981) as cited in Helsen, (2014) posit that adverse selection and credit rationing can occur when lending institutions require collateral for credit advanced. They argue that since lowrisk borrowers expect a lower rate of return if the rate of inflation is high, they are on the average less wealthy than high-risk borrowers and unable to provide more collateral for extra credit. Hence, as the collateral requirements for loans by banks increase, adverse selection is inevitable as in the case for high interest rates. Altogether, low risk borrowers are eliminated from the stream of potential borrowers and banks may not be interested in granting loans to them. The most important conclusion from Stiglitz and Weiss argument is that information asymmetry results to adverse selection and moral hazard (Malhotra, 2015). This is a source of market inefficiency in developing countries and leads to low risk borrowers such as SMEs being sidelined or even excluded from the stream of potential borrowers. In the context of the study, the theory backs the study in respect to the hindrance of access to finance by SMEs in Rwanda. The theory has demonstrated that information asymmetry results into owners financing decisions on SMEs. Hence, credit guarantee schemes are an appropriate tool to remove the barriers for SMEs access to finance in the Rwandan context.

\section{Pecking Order Theory}

The pecking order theory, which was propounded by Myers and Majluf, (1984) as cited in Jibran, Wajid, Waheed, and Muhammad (2012) states that firms prefer internal equity to external debt. When a firm needs financial resources it can choose between internal financing and external financing. Thus, the theory asserts that capital structure is driven by firm's desire to finance new investments first internally, then with low-risk debt, and finally if all fails, with equity. Therefore, the firms prefer internal financing to external financing (Tri Gunarsih, 2017).

According to Tri Gunarsh (2017) small firms are opaque and have important adverse selection problems that are explained by credit rationing; they bear high information costs. Hence, the quality of small firms' financial statements varies with some having higher levels of asymmetric information. Moreover, though investors may prefer audited financial statements, small firms may want to avoid these costs (Maimako and Olayinka, 2011). Therefore, when issuing new capital, those costs are very high, but for internal funds, the costs are considerably low. For debt, the costs are in an intermediate position between equity and internal funds. As a result, firms prefer first internal financing and then debt and they choose equity as a last resort (Tri Gunarsih, 2017)

In the context of the study, pecking order theory demonstrates the dilemma of SMEs in providing accurate financial statement given the high costs involved in hiring financial experts. Consequently, SMEs prefer internal funding to external funding such as bank credit (Jibran, et al, 2012). This further complicates their dilemma in terms of growth and expansion as I the case o Rwandan SMEs. 


\section{Methodology}

\section{Research Design}

This study used mixed methods of research design. According to Elahi and Dehdashti (2011), the research design is appropriate when the research objectives involve: portraying features of a social or physical phenomenon and determining the frequency of occurrence; examining the degree to which the variables are associated and making predictions regarding the occurrence of social or physical phenomena.

Both qualitative and quantitative research approach were used. According to Zikmund, Babin, Carr and Griffin (2010) qualitative research is concerned with understanding the social phenomenon from the participants' perspective while quantitative research is an inquiry into an identified problem, based on testing a theory, measured with numbers, and analyzed using statistical techniques. Combining the two approaches provides a richer presentation of the reality according to Silverman (2005). The study combined the two approaches to examine the influence of debt finance structure on the growth of small and medium size manufacturing enterprises in Rwanda.

\section{Target Population}

The target population of this study was 868 SMEs in the manufacturing sector licensed under the Rwanda Development Board (RDB, 2017). The SMEs provided information on constraints they face when attempting to access finance.

\section{Sampling Frame and Size}

The sampling frame for the study was drawn from the ministry of Trade and Industry database (the line ministry for RDB) that promotes industry and entrepreneurial development through facilitation of SMEs to access markets and finance.

\section{Data Processing and Analysis}

The data was collected and analyzed with respect to the study objectives, using both descriptive and inferential statistics. The tool of analysis adopted in this study was Statistical Package for Social Sciences (SPSS) version 21 for descriptive data and advanced Microsoft excel for quantitative data. The data was analyzed using descriptive statistics such as percentages, means, and standard deviation.

\section{Response Rate}

In this study, a total of 273 questionnaires were administered to the selected respondents. The questionnaires that were dully filled and returned were 225 while 48 were not properly filled and some were not returned. The study recorded a response rate of $82 \%$ which according to Fosnacht (2013) is above the acceptable response rate of $75 \%$ considered as adequate for the study. 
INTERNATIONAL JOURNAL OF ACADEMIC RESEARCH IN BUSINESS AND SOCIAL SCIENCES

Vol. 9, No. 6, June, 2019, E-ISSN: 2222-6990 @ 2019 HRMARS

Table 4.1 Response Rate

\begin{tabular}{lll}
\hline & Frequency & Percentage \\
\hline Returned Questionnaires & 225 & $82 \%$ \\
Non Responses & 48 & $18 \%$ \\
Total & $\mathbf{2 7 3}$ & $\mathbf{1 0 0}$ \\
\hline
\end{tabular}

\section{Gender of the Respondents}

Figure 4.1 indicates that $55 \%$ of the respondents were male while $45 \%$ of the respondents were female. The study finding implies that information collected by the study was gender representative and further the findings implied that small business in manufacturing enterprises in Rwanda were operated by people from both gender. The findings further shows that women just like their male counterparts are stepping forward to be involved in meaningful economic activities to generate income contrary to the past where economic activities were dominated by men.

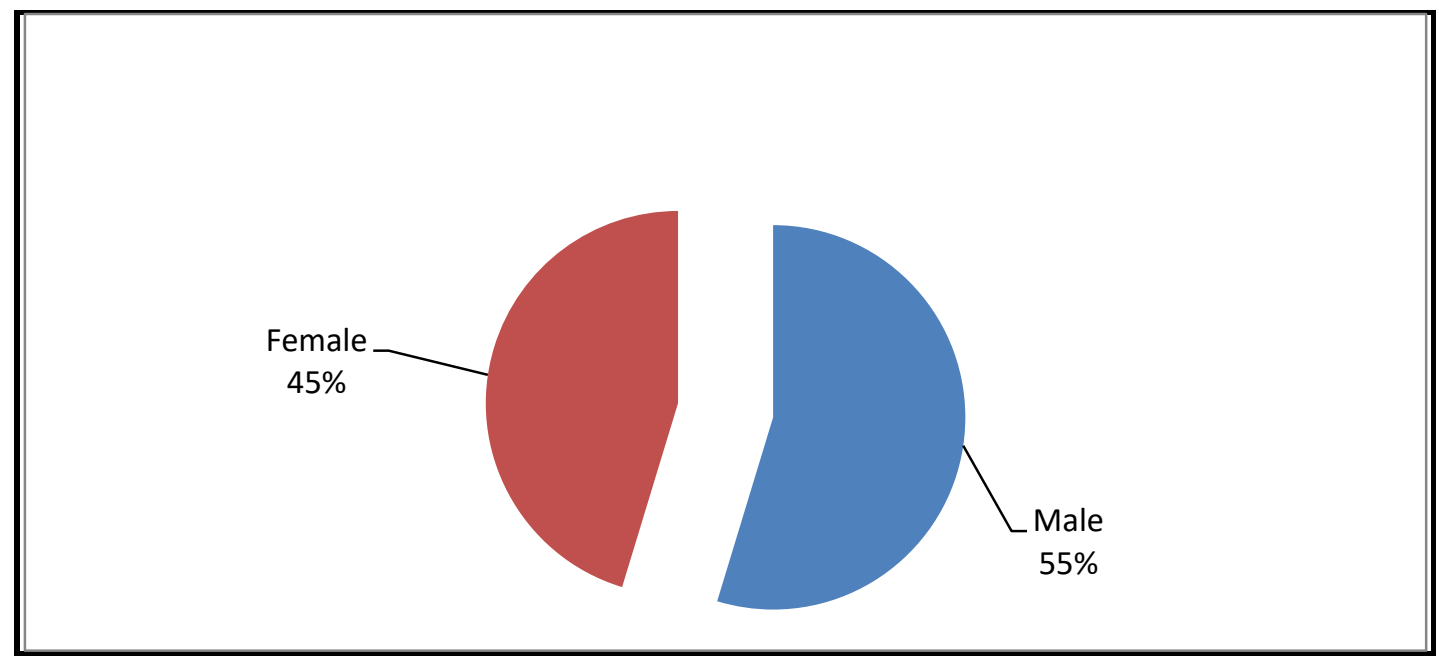

Figure 4.1 Gender of the Respondents

\section{Effect of Trade Credit Finance structure on SMEs Growth}

The first objective of the study was to investigate the effect of trade credit finance structure on the growth of manufacturing SMEs in Rwanda. The study used various tests which include factor analysis, descriptive and inferential statistics to establish the influence of trade credit finance on growth of manufacturing SMEs in Rwanda.

\section{Factors Analysis for Trade Credit Finance structure Indicators}

The findings of factor analysis presented in Table 4.2 shows that all the factors used to measure trade credit finance had factor loadings above the threshold of 0.4 adopted by the study. The findings imply that all the factors had significance in terms of explaining the trade credit finance hence none of the constructs was removed. 
INTERNATIONAL JOURNAL OF ACADEMIC RESEARCH IN BUSINESS AND SOCIAL SCIENCES

Vol. 9, No. 6, June, 2019, E-ISSN: 2222-6990 @ 2019 HRMARS

Table 4.2 Factors Analysis for Trade Credit Finance Indicators

1. Customers always honor their commitment to make payment in agreed credit period

Factor

Loadings

2. Appropriate credit period creates repeat business for my company

0.759

The business considers the length of credit period for the customer before trade credit approval

0.753

3. The business prefers giving favorable credit terms and standards to customers than cash sales in return of long-term relationship building

4. The business receives payments from suppliers based on contract credit terms and standards

5. Shorter and strict credit terms and standards reduce sales revenue for my business

0.728

6. Business trade discounts do not conflict with the liquidity demands of my firm

Customers' loyalty and goodwill increase whenever I offer favorable trade discount facilities

0.637

7. Business grants trade discount only to big organizations

0.805

Extraction Method: Principal Component Analysis.

\section{Descriptive Results on Trade Credit Finance structure}

Table 4.3 presents the descriptive results of trade credit finance. The study used percentages, mean and standard deviation to analyze the respondents' feedbacks on the statements used to measure the influence of trade credit finance on growth of SMEs in Rwanda as demonstrated below. 
INTERNATIONAL JOURNAL OF ACADEMIC RESEARCH IN BUSINESS AND SOCIAL SCIENCES

Vol. 9, No. 6, June, 2019, E-ISSN: 2222-6990 @ 2019 HRMARS

Table 4.3 Descriptive Results on Trade Credit Finance structure

StdD

SD

D

NS

A

SA

Mean

ev

1. Customers always honor their commitment to make payment in agreed credit period

$2.7 \%$

$28.0 \%$

$6.7 \%$

$46.7 \%$

$16.0 \%$

1.14

2. Appropriate credit period creates repeat business for my company 2.7

3. The business considers the length of credit period for the customer before trade credit approval

4. The business prefers

.

$\begin{array}{lllllll}2.7 \% & 37.3 \% & 10.7 \% & 44.0 \% & 5.3 \% & 3 & 1.06\end{array}$
giving favorable credit terms and standards to customers than cash sales in return of long-term relationship building

5. The business receives payments from suppliers based on contract credit terms and standards

\section{0}

6. Shorter and strict credit terms and standards reduce sales revenue for my business

7. My business trade discounts do not conflict with the liquidity demands of my firm

然

and goodwill increase whenever I offer favorable trade discount facilities 9. My business grants trade

13.3

$13.3 \%$

$24.0 \%$

$5.3 \%$

$53.3 \%$

$4.0 \%$

3

1.21

discount only to big organizations

28.0

$\begin{array}{llllll}28.0 \% & 32.0 \% & 2.7 \% & 33.3 \% & 4.0 \% & 3\end{array}$


The study sought to establish whether customers always honor their commitment to make payment in agreed credit period, the results showed that respondent had varying opinions as indicated by $46.7 \%$ and $16.0 \%$ who agree and strongly agree respectively and $28.0 \%$ and $2.7 \%$ who disagree and strongly disagree respectively. The findings implied that in some small and medium manufacturing enterprises customers honored their commitment while in other others customer failed to honor their commitments.

The study further sought to establish whether appropriate credit period creates repeated business for SMEs. Some of the respondents agree (44.0\%) while other disagree (37.3\%). The findings imply that appropriate credit period create repeat business in some firms while in others it did not. On whether manufacturing SMEs consider the length of credit period for the customers before trade credit approval, more than half (53.3\%) of the respondents agree. The study further sought to establish whether manufacturing SMEs in Rwanda preferred giving favorable credit terms and standards to customers than cash sales in return of long-term relationship building. The findings show that some firms do as indicated by $41.3 \%$ who agree while others don't as indicated by $34.7 \%$ who disagree. The mean of 3 confirmed that respondent had varying views on use of favorable credit terms and standards to customers in return of long-term relationship building. Furthermore, the study sought to establish whether manufacturing SMEs receives payments from suppliers based on contract credit terms and standards, the study finding showed that majority (64.0\%) of the respondents agreed. On whether shorter and strict credit terms and standards reduce sales revenue for their business, $42.7 \%$ and $5.3 \%$ of the respondents agree and strongly agree respectively while $29.3 \%$ and $10.7 \%$ disagree and strongly disagree respectively.

The findings in this section confirm that manufacturing SMEs in Rwanda use trade credit finance in their business. Trade credit is mainly used to build customer loyalty and increase repeat purchase from their customers which leads to growth of businesses. The finding concurs with Rodriguez (2006) who argues that through trade credit, suppliers can reduce the transaction costs associated with the insolvency of each individual commercial exchange. Trade credit helps SMEs to establish a stable commercial relationship in long run. SMEs receive more capital from market, gaining more investment and growth opportunities through the use of trade credit finance structure.

\section{Correlation Analysis for Trade Credit Finance structure and SMEs Growth}

The study further used correlation analysis to test the association between trade credit finance and growth of the manufacturing SMEs in Rwanda. Table 4.4 revealed trade credit finance had a weak positive association with growth of manufacturing SMEs in Rwanda as shown by $r=0.428$ and $p=0.000$. The correlation is significant at the level of significance of 0.05 . The results imply that increasing trade credit finance would lead to increase in growth of manufacturing SMEs in Rwanda. The finding concurs with Rodriguez (2006) who argued that through trade credit, suppliers can reduce the transaction costs associated with the insolvency of each individual commercial exchange. Trade credit helps SMEs to establish a stable commercial relationship in long run and that SMEs receive more capital from market, gaining more investment and growth opportunities through the use of trade credit finance structure. 
INTERNATIONAL JOURNAL OF ACADEMIC RESEARCH IN BUSINESS AND SOCIAL SCIENCES

Vol. 9, No. 6, June, 2019, E-ISSN: 2222-6990 @ 2019 HRMARS

Table 4.4 Correlation Analysis for Trade Credit Finance structure and SMEs Growth

\begin{tabular}{llll}
\hline & & Trade Credit Finance & Growth SMEs \\
\hline \multirow{3}{*}{ Trade Credit Finance } & Pearson Correlation & 1 & $0.428^{* *}$ \\
& Sig. (2-tailed) & & .000 \\
& $\mathrm{~N}$ & 225 & 225 \\
Growth of SMEs & Pearson Correlation & $0.428^{* *}$ & 1 \\
& Sig. (2-tailed) & .000 & \\
& $\mathrm{~N}$ & 225 & 225 \\
\hline
\end{tabular}

**. Correlation is significant at the 0.05 level (2-tailed).

Univariate Regression Analysis of Trade Credit Finance structure and SMEs growth

The study further used univariate regression to test the influence of Trade Credit Finance on the growth of small and medium manufacturing enterprises in Rwanda. The results of the regression analysis are presented in table 4.5 to 4.7.

Table 4.5 Model Summary Trade Credit and SMEs Growth

\begin{tabular}{llllll}
\hline Model & $\mathrm{R}$ & R Square & Adjusted R Square & $\begin{array}{l}\text { Std. Error of the } \\
\text { Estimate }\end{array}$ & \\
\hline 1 & $0.428^{\mathrm{a}}$ & 0.183 & 0.179 & .43433 & \\
\hline
\end{tabular}

a. Predictors: (Constant), Trade Credit Finance

Table 4.5 shows coefficient of determination (R-square) $=0.183$ which implies that other factors held constant, trade credit finance accounted for $18.3 \%$ of the variation in growth of the manufacturing SMEs in Rwanda. The findings further mean that trade credit finance is a good predictors' variable of growth of small and medium manufacturing enterprises in Rwanda. The results corroborate with Rodriguez (2006) who found that SMEs receive more capital from market, gaining more investment and growth opportunities through the use of trade credit finance structure.

Table 4.6 ANOVA for Trade Credit Finance structure and SMEs Growth

\begin{tabular}{lllllll}
\hline Model & & Sum of Squares & $\mathrm{df}$ & Mean Square & $\mathrm{F}$ & Sig. \\
\hline \multirow{2}{*}{1} & Regression & 9.421 & 1 & 9.421 & 49.941 & $.000^{\mathrm{b}}$ \\
& Residual & 42.067 & 223 & .189 & & \\
& Total & 51.488 & 224 & & & \\
\hline
\end{tabular}

a. Dependent Variable: Growth of SMEs

b. Predictors: (Constant), Trade Credit Finance

Table 4.6 presents the findings on the analysis of the variance (ANOVA) of the model used to link trade credit finance structure and growth of small and medium manufacturing enterprises in Rwanda. The results of $F=49.941$ with a corresponding $P=0.000$ shows that the model was statistically significance, hence the study failed to reject the null hypothesis the goodness of fit. The finding further implied that trade credit finance significantly explained the variation in growth of 
INTERNATIONAL JOURNAL OF ACADEMIC RESEARCH IN BUSINESS AND SOCIAL SCIENCES Vol. 9, No. 6, June, 2019, E-ISSN: 2222-6990 (C) 2019 HRMARS

manufacturing SMEs in Rwanda. Similarly, Boissay and Gropp, (2007) and Cunat (2007) demonstrate that trade credit provides a safety valve for firms facing distinctive liquidity shocks.

Table 4.7 Regression Coefficients for Trade Credit Finance structure and SMEs Growth

\begin{tabular}{llllll}
\hline & $\beta$ & Std. Error & Beta & t & Sig. \\
\hline (Constant) & 2.743 & 0.115 & & 23.9 & 0.000 \\
Trade Credit Finance & 0.250 & 0.035 & 0.428 & 7.067 & 0.000 \\
\hline
\end{tabular}

a Dependent Variable: Growth of SMEs

Table 4.7 presents the findings of regression coefficients of trade credit finance structure and growth of small and medium manufacturing enterprises. The study results showed $\beta=0.250, p=0.000<0.05$. These findings imply that trade credit finance has a positive and significant effect on growth of manufacturing SMEs in Rwanda. Other factors held constant, a unit increase in trade credit finance would results into an increase of 0.250 units in growth of small and medium manufacturing enterprises in Rwanda.

The findings concur with Rodriguez (2006) who posited that through trade credit, suppliers reduce the transaction costs associated with the insolvency of each individual commercial exchange. Trade credit helps SMEs to establish a stable commercial relationship in long run. SMEs receive more capital from market, gaining more investment and growth opportunities through the use of trade credit finance structure.

\section{Effect of Debt Finance structure on SMEs Growth}

The second objective of the study was to examine the influence of debt finance structure on the growth of small and medium manufacturing enterprises in Rwanda. The findings of factors analysis, descriptive statistics and inferential statistics on the influence of debt finance structure on growth of small and medium manufacturing enterprises are presented as follows:

\section{Factors Analysis for Debt Finance structure Indicators}

The findings of factor analysis presented in Table 4.8 shows that all the factors used to measure debt finance structure had factor loadings above the threshold of 0.4 adopted by the study. The findings imply that all the factors had significance in terms of explaining the debt finance structure hence none of the constructs was removed because they loaded appropriately. The factor loadings varied between 0.524 and 0.825 . 
INTERNATIONAL JOURNAL OF ACADEMIC RESEARCH IN BUSINESS AND SOCIAL SCIENCES

Vol. 9, No. 6, June, 2019, E-ISSN: 2222-6990 @ 2019 HRMARS

Table 4.8 Factors Analysis for Debt Finance structure Indicators

\begin{tabular}{ll}
\hline Debt Finance Indicators & Factor Loadings \\
\hline $\begin{array}{l}\text { 1. Affordable interest rates charged by lenders have had a positive impact } \\
\text { on my business }\end{array}$ & 0.809 \\
$\begin{array}{l}\text { 2. High interest rates have influenced my business to refrain from } \\
\text { accessing debt finance }\end{array}$ & 0.731 \\
$\begin{array}{l}\text { 3. Affordable Interest rates influence my decision to acquire debt finance } \\
\text { for the business }\end{array}$ & 0.787 \\
$\begin{array}{l}\text { 4. Business financing decisions are formulated based on interest rates } \\
\text { costs }\end{array}$ & 0.610 \\
$\begin{array}{l}\text { 5. The high collateral requirements negatively affect access to business } \\
\text { finance }\end{array}$ & 0.825 \\
$\begin{array}{l}\text { 6. Having assets to give as a collateral requirement has enabled my } \\
\text { company to access debt finance }\end{array}$ & 0.746 \\
$\begin{array}{l}\text { 7. The lenders ask me for additional collateral whenever I fail to fulfill my } \\
\text { monthly repayment plans }\end{array}$ & 0.524 \\
$\begin{array}{l}\text { 8. Long-term debt repayment periods motivate me to acquire extra } \\
\text { amount of loan for my business }\end{array}$ & 0.596 \\
$\begin{array}{l}\text { 9. Past investment successes motivate me to acquire a bigger amount of } \\
\text { debt }\end{array}$ & 0.575 \\
$\begin{array}{l}\text { 10. Business assets market value determines the size of loan advanced to } \\
\text { my business }\end{array}$ & \\
$\begin{array}{l}\text { 11. The business has fully utilized the loan facility according to its } \\
\text { investment potential }\end{array}$ & 0.706 \\
\hline
\end{tabular}

Extraction Method: Principal Component Analysis.

\section{Descriptive Results on Debt Finance structure}

Table 4.9 indicates percentages, mean and standard deviation the study used to analyze how respondents responded to various statement used to measure the influence of debt finance structure on growth influence in Rwanda. The findings on different study attributes are presented as follows: 
INTERNATIONAL JOURNAL OF ACADEMIC RESEARCH IN BUSINESS AND SOCIAL SCIENCES

Vol. 9, No. 6, June, 2019, E-ISSN: 2222-6990 @ 2019 HRMARS

Table 4.9 Descriptive Results on Debt Finance structure

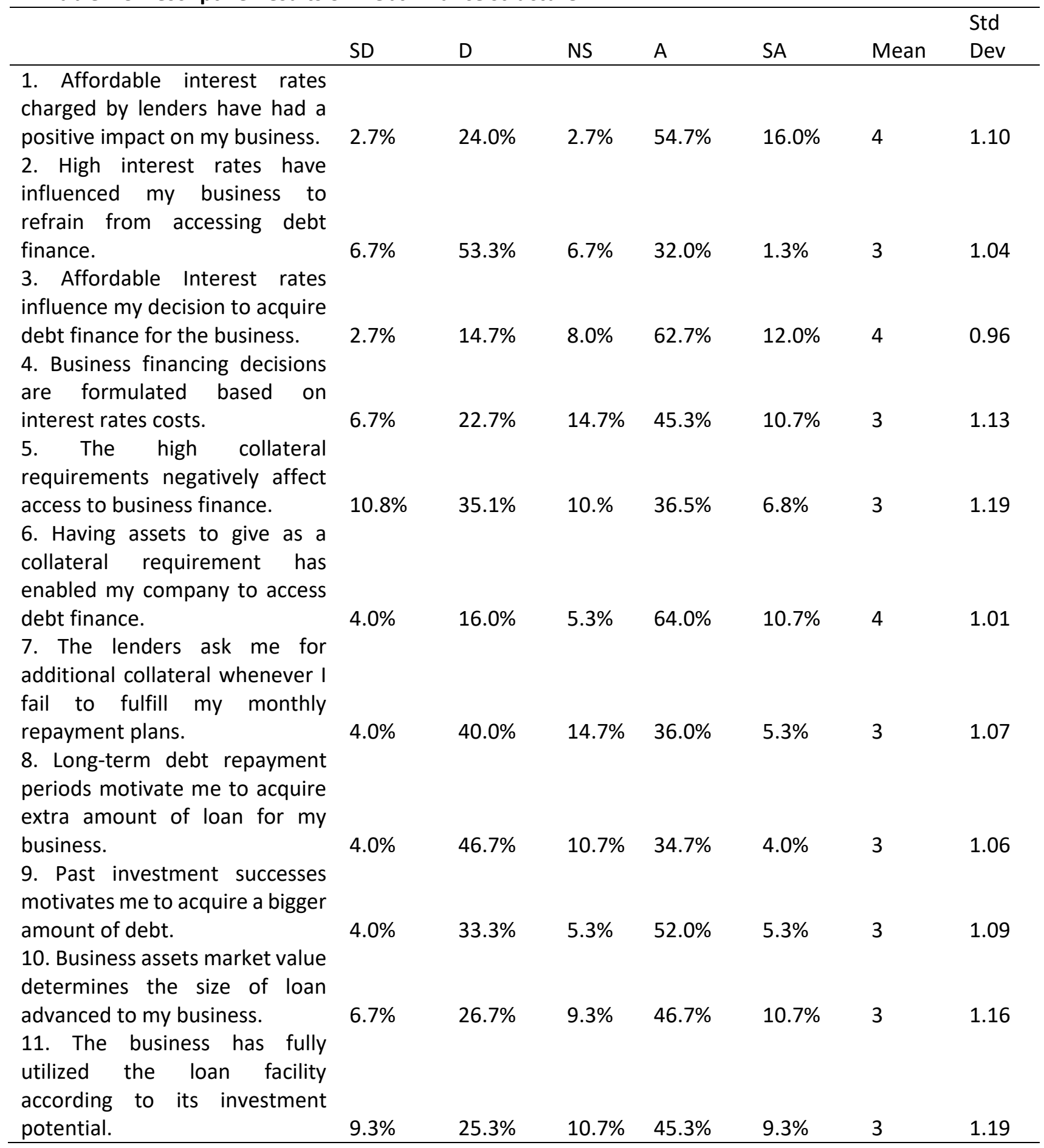

The study sought to establish whether affordable interest rates charged by lenders have a positive impact on small manufacturing businesses in Rwanda, The findings show that $54.7 \%$ and $16.0 \%$ agreed and strongly agree respectively. On whether high interest rates have influence on small 
manufacturing businesses in terms of refraining from accessing debt finance, $53.3 \%$ of the respondents disagree while $32.0 \%$ agree implying that some manufacturing SMEs failed to access debt finance due to high interest rates while others accessed despite high interest rates charged.

The finding further shows that $62.7 \%$ and $12.0 \%$ agree and strongly agree respectively that affordable interest rates influence their decision to acquire debt finance for the business. On whether business financing decision are formulated based on interest rates costs, $45.3 \%$ and $10.7 \%$ agree and strongly agree respectively while $22.7 \%$ and $6.7 \%$ disagree and strongly disagree respectively. Similarly, on whether high collateral requirements negatively affect access to business finance, the study findings show that respondents had varying opinions as shown by $36.5 \%$ who agree and $35.1 \%$ who disagree. The findings showed that $64.0 \%$ of the respondents agree that having assets to give as a collateral requirement had enabled their company to access debt finance. The findings imply that majority of the SMEs that participated in the study had accessed debt finance by providing collaterals.

Generally, the study established the varying opinions on the use and access of debt finance by small manufacturing businesses in Rwanda. Some of the business agreed that debt finance was accessible and influence the growth of the business while other found it hard to access debt finance. The study further established the collateral played a critical role in accessing debt finance by small manufacturing businesses in Rwanda. The finding concurs with Falkena, Bomber and Llewellyn (2001) who argued that banks usually rely on collateral to recover the money invested in a particular business when the SMEs default on the loan commitments. The findings also concur with Cole, (2003) who found that loans issued to SMEs are usually short term and the rate of interest is often high. The author further argued that most of the lenders are unlikely to provide unsecured loans to the small businesses unless there was a lot of business that were made in the past between the borrower and lender, otherwise the lender will still insist that the borrower provide collateral for the loans.

\section{Correlation Analysis for Debt Finance structure and SMEs of Growth}

The study used correlation analysis to test the association between debt finance and growth of the manufacturing SMEs in Rwanda. Table 4.10 reveal that debt finance structure has a weak positive association with growth of manufacturing SMEs in Rwanda as shown by $r=0.249$ and $p=0.000$. The correlations were significant at the level of significance of 0.05 . The results implied that increasing debt finance would lead to increase in growth of manufacturing SMEs in Rwanda. This study finding corroborates with Fatoki and Smith, (2011) who found that bank financing is important for the growth of small firms. Young businesses and any other enterprises in the world including SMEs depend mostly on bank financing to boost the business and to carry out new investments and projects. 
INTERNATIONAL JOURNAL OF ACADEMIC RESEARCH IN BUSINESS AND SOCIAL SCIENCES

Vol. 9, No. 6, June, 2019, E-ISSN: 2222-6990 @ 2019 HRMARS

Table 4.10 Correlation Results on Debt Finance structure and SMEs of Growth

\begin{tabular}{llll}
\hline & & Debt Finance & Growth of SMEs \\
\hline \multirow{3}{*}{ Debt Finance } & Pearson Correlation & 1 & $0.249^{* *}$ \\
& Sig. (2-tailed) & & .000 \\
& $\mathrm{~N}$ & 225 & 225 \\
Growth of SMEs & Pearson Correlation & $0.249^{* *}$ & 1 \\
& Sig. (2-tailed) & .000 & \\
& $\mathrm{~N}$ & 225 & 225 \\
\hline
\end{tabular}

**.Correlation is significant at the 0.05 level (2-tailed).

Univariate Regression Analysis Debt Finance structure and SMEs growth

The study conducted a univariate regression analysis to test the influence of debt finance on the growth of manufacturing SMEs in Rwanda. The findings of model summary (coefficient of determination) ANOVA and regression coefficients are provided in Tables 4.11 to 4.13.

Table 4.11 Model Summary Debt Finance structure and Manufacturing SMEs Growth

\begin{tabular}{llllll}
\hline Model & $\mathrm{R}$ & R-Square & Adjusted R-Square & $\begin{array}{l}\text { Std. Error of the } \\
\text { Estimate }\end{array}$ & \\
\hline 1 & $.249^{\mathrm{a}}$ & .062 & .058 & .46537 & \\
\hline
\end{tabular}

a. Predictors: (Constant), Debt Finance

Table 4.11 shows that R-square for the model used to link debt finance and growth of manufacturing SMEs in Rwanda was 0.062 . These results imply that other factors held constant, debt finance accounts for $6.2 \%$ of the growth of manufacturing SMEs in Rwanda. The findings further mean that debt finance influences SMEs' growth although by a small percentage. The study finding concurs with Fatoki and Smit, (2011) who found that bank financing is important for the growth of small firms.

Table 4.12 ANOVA for Debt Finance structure and SMEs Growth

\begin{tabular}{lllllll}
\hline Model & & Sum of Squares & $\mathrm{df}$ & Mean Square & $\mathrm{F}$ & Sig. \\
\hline \multirow{2}{*}{1} & Regression & 3.193 & 1 & 3.193 & 14.745 & $.000^{\mathrm{b}}$ \\
& Residual & 48.295 & 223 & .217 & & \\
& Total & 51.488 & 224 & & & \\
\hline
\end{tabular}

a. Dependent Variable: Growth of SMEs

b. Predictors: (Constant), Debt Finance

Table 4.12 presents the findings on the analysis of the variance (ANOVA) of the model used to link debt finance and growth of manufacturing SMEs in Rwanda. The results of $F=14.745$ with a corresponding $p=0.000$ shows that the model was statistically significance, hence the study failed to reject the null hypothesis the goodness of fit. The finding further implied that debt finance structure significantly explained the variation in growth of manufacturing SMEs in Rwanda. 
INTERNATIONAL JOURNAL OF ACADEMIC RESEARCH IN BUSINESS AND SOCIAL SCIENCES Vol. 9, No. 6, June, 2019, E-ISSN: 2222-6990@ 2019 HRMARS

Table 4.13 Regression Coefficients for Debt Finance structure and SMEs Growth

\begin{tabular}{llllll}
\hline & $\beta$ & Std. Error & Beta & $t$ & Sig. \\
\hline (Constant) & 3.041 & 0.131 & & 23.296 & 0.000 \\
Debt Finance & 0.152 & 0.039 & 0.249 & 3.84 & 0.000 \\
\hline
\end{tabular}

a Dependent Variable: Growth of SMEs

Table 4.13 shows a beta value of $\beta=0.152, P=0.000<0.05$. These findings imply that debt finance structure has a positive and significant effect on growth influence in Rwanda when all other factors are held constant. A unit increase in debt finance would results to increase on 0.152 units in growth of manufacturing SMEs. The study finding concurs with Fatoki and Smit, (2011) who found that bank financing is important for the growth of small firms. Young businesses and any other enterprises in the world including SMEs depend mostly on bank financing to boost the business and to carry out new investments and projects.

\section{Conclusion}

The study investigated the influence of debt finance structure finance on the growth of manufacturing SMEs in Rwanda. The study objectives were two; to investigate the influence of trade credit finance structure on the growth of manufacturing SMEs in Rwanda and to examine the influence of debt finance structure on the growth of small and medium manufacturing enterprises in Rwanda. The study employed various tests which include factor analysis, descriptive and inferential statistics such as correlation analysis to test the association between study variables and answer study questions. The findings reveal that trade credit finance has a moderate positive association with growth of manufacturing SMEs in Rwanda. The results imply that increasing trade credit finance would lead to increase in growth of manufacturing SMEs in Rwanda. Findings of regression analysis indicate that trade credit finance has a positive and significant effect on growth of the manufacturing SMEs in Rwanda when other factors are held constant. Hence, a unit increase in trade credit finance would results into an increase of 0.250 units in growth of manufacturing SMEs. The study therefore, rejected the null hypothesis $\mathrm{HO}_{1}$ that: There is no significant influence of trade credit finance structure on the growth of manufacturing SMEs in Rwanda.

With regard to debt finance, findings of correlation analysis revealed that debt finance had a weak positive relationship with growth of manufacturing SMEs in Rwanda. Hence, increasing debt finance would to a very small extent lead to increase in growth of manufacturing SMEs in Rwanda. In the multivariate model, the coefficient for debt finance structure was found to be insignificant. The findings implied that debt finance structure had an insignificant influence on growth of manufacturing SMEs in Rwanda. The study therefore, failed to reject null hypothesis $\mathrm{HO}_{2}$ that: there is no significant influence of debt finance structure on the growth of manufacturing SMEs in Rwanda. The study findings implied that in manufacturing SMEs in Rwanda debt financing cannot be significantly utilized to enhance their growth.

In all, this study established that debt financial structure particularly trade credit plays a critical role in expansion and growth of small and medium manufacturing enterprise in Rwanda. Trade credit finance structure had the most significant effect of growth of the small and medium manufacturing 
enterprise in Rwanda. Based on the findings, the study concludes that small and medium enterprises that use trade credit finance in their financial structure have high probability of the achieving their growth objectives since trade credit ensures that firms continue to be serviced by their suppliers on credit and the available resources can be channeled into other growth opportunities unlike firms which use their available resources to pay suppliers. On the relationship between debt finance and growth of the small and medium manufacturing enterprise the study concludes that debt finance is the least in supporting the growth of the these SMEs. This is because lack of access to debt by small business due to risk perception and lack of adequate collaterals required by the lending institutions. Only small business that meet the strict demands by lending institutions can use debt finance to support growth.

\section{Contribution of the Study}

This study makes a contribution that is both theoretically and contextually significant: Theoretically, the fact that the study finds the use of debt finance as having no significance to fueling SME growth in Rwanda further confirms the stipulations of the credit rationing theory. The theory claims that interest that banks charge on loans have the tendency to affect the risks of a pool of loans by either sorting potential borrowers (adverse selection effect) or affecting the behavior of borrowers (moral hazard effect). Perhaps the insignificance of debt finance structure is associated with the reluctance of SMEs to indulge in borrowing from banks given the high interest rates charged by banks, high risks involved in debt financing as well the difficult collateral requirement which act as a disincentive to SME borrowing.

Similarly, the fact that the study finds the use of trade credit by SMEs in Rwanda having a significant influence on growth of manufacturing SMEs also validates one of the assertions of the pecking order theory which maintains that capital structure is driven by firm's desire to finance new investments first internally, then with low-risk debt, and finally if all fails, with equity. Therefore, the firms prefer internal financing to external financing (Tri Gunarsih, 2017). In this case, the use of trade credit can be seen as a low risk debt option.

Contextually, the fact that a lot of manufacturing SMEs in Rwanda struggle financially (Nikubwimana, 2016) means they can explore avenues to take advantage of trade credit to leverage their growth as evidence from this study suggest that use of trade credit could potentially enhance growth of SMEs in Rwanda by 0.250 (25\%) other factors holding constant.

\section{Recommendations}

The management of the SMEs in Rwanda ought to learn how to use trade credit particularly account receivables and account payables to fully take advantage of trade credit finance structure. This will ensure that SMEs continue producing or manufacturing during time of low liquidity. The study also recommends that lending institution should revise their lending models to SMEs to increase access to credit by small businesses for growth purposes. 
INTERNATIONAL JOURNAL OF ACADEMIC RESEARCH IN BUSINESS AND SOCIAL SCIENCES

Vol. 9, No. 6, June, 2019, E-ISSN: 2222-6990 (C) 2019 HRMARS

\section{References}

Akinyi, S. (2012). The effect of bank financing on the financial performance of small and medium sized enterprises in Nairobi County. Masters Thesis University of Nairobi.

AfDB annual report, (2013). Report by the board of governors of the African Development Bank and the African Development Fund covering the period from 1 January - December 31, 2013. Kigali, Rwanda. African Development Bank

Andries, A. M. Marcu, N., Oprea, F. \& Tofan, M. ( 2018). Financial Infrastructure and Access to Finance for European SMEs. Sustainability, 10, PP 340.

Bancilhon, C., Karge, C. 7 Norton, T. (2018 ). Win-Win-Win: The Sustainable Supply Chain Finance Opportunity. BSR Report, Paris Available at:

https://www.bsr.org/reports/BSR_The_Sustainable_Supply_Chain_Finance_Opportunity.pdf

Boissay, F. G. \&. Gropp, R. (2007). Trade credit defaults and liquidity provision by firms. European Central Bank working paper series 753.

Cole, R. A. (2003). How did the financial crisis affect small business lending in the US? Driehaus College of Business DePaul University.

European Union, EU (2018). Annual Report on European SMEs 2014/2015; European Union: Luxembourg.

Cuñat, V. (2007). Trade credit: Suppliers as debt collectors and insurance providers. Review of Financial Studies 20(2) , pp. 491-527.

Elahi, M. \& Dehdashti, M. (2011). Classification of Researches and Evolving a Consolidation Typology of Management Studies London. The Center for Innovations in Business and Management Practice.

Falkena, H., Bomber, R. \& Llewellyn, D. (2001). Financial regulation in South Africa. Researgate.

Fatoki, O. O. \&. Smit, V. A. (2011). Constraints to credit access by new SMEs in South Africa: A supplyside analysis. . African Journal of Business Management Vol. 5(4), pp. 1413-1425,.

Fosnacht, K. (2013). undergraduate coping with financial stress; a latent class analysis paper presented at the annual meeting of American College Personnel Association Las Vegas, NV.

Garikai, W. (2011). Ga Growth of SMEs in Developing Nations: Special Reference to AGOA.

Helsen, F. (2014). Collateral and Credit Rationing:The role of collateral in explaining and remediating the limited flow of credit to households and SMEs. European Credit Research Institute, ECRI Policy Brief No. 7 .

Hussain, T. S., Khan, U., Malik, Z. K. \& Faheem, A. (2012). Constraints faced by Industry in Punjab, Pakistan. .

Jibran, S., Wajid, A., Iqbal, W. \& Muhammad, T. M (2012). Pecking at Pecking Order Theory: Evidence from Pakistan's Non-financial Sector Journal of competitiveness. 4, (4), PP (86-95).

Kwaak, T., Van der Graaf, A. \& Van der Zeijden, P. (2016) Survey on the Access to Finance of EU enterprises, Analytical Report 2016. European Commission

Maimako, S. \& Olayinka, M. (2011). Financing choices: A test of the pecking order theory.The Nigerian Accounting Horizon. 
Malhotra, P. (2015). To what extent does the theory of credit rationing explain the phenomenon of microfinance? University of Auckland. Research gate Accessed on line at: file://C:/Users/ffrrr/Downloads/Honours_Dissertation_Pawani_Malhotra.pdf.

Ministry of Trade and Commerce, MINECOM (2010) Small and Medium Enterprises (SMEs) Development policy, Kigali.

Mwangi, M. \& Otieno, L. (2013 ). Commercial banks perception on the financing of small and medium enterprises (SME) A study of Western region Masters' Thesis University of Nairobi.

Ndikubwimana, P. (2016). The role of financial institutions in promoting innovation of SMEs in Rwanda; An empirical review. British journal of Economics, Management and Trade 14(2): 2016, article n0. BJEMT.26746 ISSN: 2278-098X , 1-14.

OECD. (2006). Financing Innovative SMEs in a Global Economy, Istanbul Turkey 3-5 June. Organisation for Economic Cooperation and Development.

OECD. (2018). Financing SMEs and Entrepreneurs 2018: An OECD Scoreboard; OECD Publishing: Paris, France.

Rodriguez, F. S. (2016). Trade credit, the finial crisis and SME access to finance. Journal of Money, Credit and Banking 48 (1).

Rungani, E. C. (2009) Determinants of capital structure of small and medium enterprises in the Buffalo City municipality, Eastern Cape Pronvince, South Africa. Mcomm Thesis. University of Fort Hare, Alice

Silverman, D. (2005). Doing Qualitative Research: A Practical Handbook. SAGE Publications.

Stiglitz, J. E. \& Wiess, A. (2011). Credit Rationing in Markets with Imperfect Information to action for psychology, . American Economic Review, 71(3) PP 393410.

Tri Gunarsih, M. (2017). Pecking order theory of capital structure and governing mechanism: Evidence from Indonesian Stock Exchange. Research gate.

Zikmund, G. B. (2010). Business Research Methods 8thed. South-Western, CengageLearning. 